\title{
Proses Berpikir Kritis Matematis Siswa Ditinjau Dari Tipe Kepribadian Ekstrovert dan Introvert
}

\author{
Rindu Rudianti', Aripin², Dedi Muhtadi ${ }^{3 *}$ \\ Pendidikan Matematika, Universitas Siliwangi \\ Jalan Siliwangi No. 24, Tasikmalaya, Jawa Barat, Indonesia \\ 1rindurudianti@gmail.com, ${ }^{2}$ aripin@unsil.ac.id, ${ }^{3 *}$ dedimuhtadi@unsil.ac.id
}

Artikel diterima: 02-04-2021, direvisi: 02-09-2021, diterbitkan: 30-09-2021

\begin{abstract}
Abstrak
Penelitian dilakukan mengingat pentingnya memperhatikan kemampuan berpikir kritis dan tipe kepribadian untuk menunjang keberhasilan belajar matematika. Penelitian ini mendeskripsikan proses berpikir kritis matematis siswa ditinjau dari tipe kepribadian ekstrovert dan introvert. Metode penelitian yaitu kualitatif eksploratif, dengan subjek sebanyak empat siswa kelas XII teknik busana butik salah satu SMK Negeri di Rajadesa. Instrumen yang digunakan yaitu tes kemampuan berpikir kritis matematis, wawancara, dan angket tipe kepribadian. Hasil penelitian menunjukkan bahwa subjek ekstrovert lebih cepat dibandingkan dengan introvert dalam menyelesaikan masalah, tetapi kurang teliti dalam menyelidiki permasalahan. Subjek ekstrovert juga menggunakan konsep yang salah ketika menarik kesimpulan, mereka tidak tepat dalam mengaitkan informasi yang ada dengan pengetahuan yang dimilikinya. Sedangkan subjek introvert, cenderung tenang, teliti, hatihati, dan memikirkan kembali solusi sebelum menarik kesimpulan. Siswa introvert mampu mengembangkan argumen dengan mengembangkan informasi yang ada dan memberikan pernyataan yang mengarah pada langkah-langkah yang diambil dalam menyelesaikan masalah, meskipun tidak dapat menuliskannya dengan tepat.

Kata Kunci: berpikir kritis, tipe kepribadian ekstrovert dan introvert.
\end{abstract}

\section{Students' Mathematical Critical Thinking Process Judging from Extrovert and Introvert Personality Types}

\begin{abstract}
The research was conducted considering the importance of paying attention to critical thinking skills and personality types to support the success of learning mathematics. This study describes students' mathematical critical thinking processes in terms of extrovert and introvert personality types. The research method is qualitative exploratory, with the subject as many as four students of class XII fashion boutique engineering one of the SMK in Rajadesa. The instruments used are mathematical critical thinking ability tests, interviews, and personality type questionnaires. The results showed that extroverted subjects were faster than introverts in solving problems but less thorough in investigating problems. Extroverted subjects also use the wrong concept when concluding, they are not right in relating the existing information to the knowledge they have. While introverted subjects tend to be calm, thorough, careful, and rethink solutions before concluding. Introverted students can develop arguments by developing existing information and providing statements that lead to the steps taken in solving problems, even though they cannot write them down correctly.

Keyword: Critical Thinking, extrovert, and introvert personality types.
\end{abstract}




\section{Pendahuluan}

Pemikiran kritis siswa adalah hasil yang diinginkan dari pembelajaran dan pengembangan pemikiran kritis telah menjadi salah satu tujuan utama pendidikan (Yeh \& Hsing-hsia, 2003: 1). Pemikiran kritis adalah pemikiran reflektif yang masuk akal serta berfokus pada cara memutuskan apa yang harus dipercaya dan dilakukan (Ennis, 1989: 10; Afriansyah, dkk., 2021), juga berkaitan dengan proses berpikir seseorang dalam memecahkan masalah secara reflektif dan berpikir logis dengan memikirkan alasan-alasan yang menunjang untuk mendapatkan keputusan yang dipercaya ataupun dilakukan (Muhtadi, dkk., 2019: 1).

Pemikir kritis menunjukkan kepercayaan diri dalam kemampuan mereka, keingintahuan intelektual, pikiran terbuka terhadap pandangan dunia yang berbeda, kejujuran tentang diri mereka sendiri, keteraturan dan kompleksitas, dan fleksibilitas untuk alternatif (Facione, 1994: 19; Masfufah \& Afriansyah, 2021). Berpikir kritis merupakan keterampilan atau strategi kognitif dalam menentukan tujuan (Apiati \& Hermanto, 2020). Berpikir kritis adalah salah satu bagian utama dalam belajar matematika dan harus dimiliki siswa di sekolah (Alexandra \& Ratu, 2018). Pengembangan proses berpikir kritis memungkinkan peserta didik untuk bekerja secara matematis dan menjadi pemecah masalah yang efektif (Luritawaty \& Prabawanto, 2021). Untuk membangun berpikir kritis dalam matematika siswa biasanya dihadapkan pada permasalahan yang kontradiktif serta baru sehingga bisa mencari kebenaran dan alasan yang jelas untuk mengambil keputusan dan dapat menyelesaikan permasalahan pada pembelajaran matematika serta mampu menghasilkan kesimpulan yang benar.

Berpikir kritis matematis merupakan suatu "kebutuhan vital" abad ke-21 khususnya dalam ledakan informasi dan syarat utama untuk melengkapi siswa dengan kemampuan "mengetahui cara belajar" dan "mengetahui cara berpikir jernih" tentang informasi yang meningkat cepat, (Halpern, 2003: 15). Berpikir kritis matematis berarti keterampilan untuk mengumpulkan, mengevaluasi dan menggunakan data secara efektif dan efisien. Pemikiran kritis mudah dihubungkan dengan penilaian rasional sebagai bidang yang luas, definisi pemikiran kritis berbeda dalam ruang lingkup dan penekanan, tetapi fokus pada proses dan hasil pembelajaran (Rezaei, Ali, \& Marzieh, 2011: 769).

Berkaitan dengan berpikir kritis, hasil penelitian Fatmawati, dkk. (2014: 917) terhadap siswa kelas $X$ di Sekolah Menengah Kejuruan (SMK) Muhammadiyah 1 Sragen dengan subjek sebanyak 36 orang menunjukkan bahwa aspek yang mempengaruhi proses berpikir kritis siswa dalam menyelesaikan soal pemecahan masalah matematik terdapat $72,2 \%$ dari 36 siswa tidak terbiasa mengerjakan soal cerita, sehingga siswa kurang menguasai soal, tidak dapat 
mengubah soal cerita ke dalam model matematika sehingga siswa sulit dalam menyelesaikan soal, cenderung menyelesaikan soal hanya dengan memakai satu cara tanpa melihat metode lain, sehingga siswa sering tidak mengecek hasil pekerjaannya ketika soal selesai dikerjakan. Namun, temuan ini mendukung klaim bahwa setiap siswa membutuhkan pemikiran kritis untuk memecahkan masalah kehidupan nyata, dan perlu juga untuk mengembangkan pembelajaran matematika yang membutuhkan pemikiran kritis untuk memahami masalah dan menemukan solusi lain. Hal ini tidak jauh berbeda dengan temuan Kusmanto (2014: 99) dan Kesumawati (2012: 48) yang meyakini bahwa ada hubungan antara pengetahuan matematika dengan berpikir kritis.

Setiap siswa adalah individu yang unik dengan karakteristik yang berbeda-beda. Perbedaan tersebut harus diterima dan digunakan oleh guru dalam proses pembelajaran. Seorang pengajar harus memperhatikan karakteristik siswa dalam pembelajaran yang tepat. Banyak faktor yang mempengaruhi adanya perbedaan tersebut, salah satunya yaitu kepribadian mereka. Kepribadian adalah karakteristik seseorang yang menyebabkan munculnya konsistensi perasaan, pemikiran, dan perilaku (Pervin, dkk., 2010: 309; Sri dan Yohanes, 2013: 108). Kepribadian diartikan sebagai organisasi dinamis dari sistem psikofisik individu yang menentukan penyesuaian dirinya terhadap lingkungan
(Friedman \& Schustack, 2008: 108). Kepribadian adalah jumlah total kecenderungan bawaan atau herediter dengan berbagai pengaruh dari lingkungan serta pendidikan, yang membentuk kondisi kejiwaan seseorang dan memengaruhi sikapnya terhadap kehidupan (Weller, 2005: 592). Menurut pendapat beberapa ahli tersebut, dapat disimpulkan bahwa kepribadian adalah berbagai perilaku berbeda yang dimiliki setiap orang dalam satu, dua atau lebih kategori menurut pola sifat yang dekat termasuk adaptasi terhadap situasi dan kondisi yang ada di lingkungannya.

Ciri-ciri kepribadian menjelaskan jumlah ragam unik pada siswa dan prestasi dalam pendidikan menengah (De Raad \& Schouwenburg, 1996: 303). Ciri-ciri kepribadian dalam individu secara sistematis mensistematiskan individu ke dalam klasifikasi yang efisien (Donnellan \& Robins, 2010: 1070).

Salah satu penyebab rendahnya kemampuan siswa dalam menyelesaikan masalah matematika diprediksi karena karakteristik mereka yang berbeda. Pendidik harus mampu memahami kepribadian siswa dan membuat proses pendidikan berkembang dengan baik, guna bisa mencapai hasil belajar yang maksimal.

Jesse, dkk. (2006: 644) mendefinisikan tipe kepribadian berdasarkan empat dikhotomi fungsi mental atau sikap, diantaranya yaitu: (1) bagaimana seseorang memandang informasi, (2) bagaimana seseorang memberikan 
penilaian atau keputusan sesuai persepsi mereka, (3) bagaimana seseorang memanfaatkan waktu dan energinya, dan (4) bagaimana gaya dasar hidup seseorang di lingkungan sekitarnya.

Dalam proses berpikir kritis, siswa cenderung memiliki karakteristik yang berbeda. Hal ini dikarenakan setiap individu memiliki pengalaman, motif, sikap dan tipe kepribadian yang relatif berbeda dalam kemampuan berpikirnya. Seorang pendidik perlu menyadari pentingnya perbedaan cara berpikir setiap siswa, salah satunya yaitu dalam proses berpikir kritis. Kepribadian bersifat unik dan konsisten, sehingga dapat digunakan untuk membedakan antara individu satu dengan lainnya. Mengenai perbedaan tipe kepribadian, Jung membagi kepribadian menjadi dua tipe, yaitu: ekstrovert dan introvert (Suryabrata, 2002: 96).

Ekstrovert adalah tipe kepribadian yang lebih mementingkan luar dirinya dan cenderung lebih membuka diri terhadap dunia luar, mereka menyukai keramaian, dengan banyak interaksi dan aktivitas sosial. Sedangkan introvert adalah tipe kepribadian yang lebih mementingkan dalam dirinya dan cenderung menutup diri dari dunia luar, mereka lebih memilih berada di tempat sepi dan suka menyendiri.

Beberapa penelitian tentang berpikir kritis dalam matematika setidaknya menunjukkan perlunya peningkatkan pengembangan proses berpikir kritis dalam matematika. Karena berpikir kritis dan matematika merupakan satu kesatuan yang tidak dapat dipisahkan. Studi yang dilakukan oleh Janssen (2019: 144) mengungkapkan tentang identifikasi terkait dengan kinerja tes refleksi kognitif guru pendidikan tinggi dan disposisi mereka terhadap pengajaran berpikir kritis, disimpulkan bahwa disposisi terhadap pemikiran kritis memiliki hubungan positif dengan Cognitive Reflection Test (CTR) atau tes refleksi kognitif. Penelitian yang dilakukan oleh Arini (2016:128) pada siswa bekepribadian ekstrovert dan introvert menunjukkan bahwa baik siswa ekstrovert maupun introvert mampu memproses informasi, tetapi siswa ekstrovert tidak dapat menghubungkan informasi yang ada. Subjek introvert lebih berhati-hati dan teliti daripada siswa ekstrovert karena memiliki perhitungan dan hasil yang salah.

Berdasarkan penelitian yang relevan, peneliti ingin mengetahui bagaimana masing-masing tipe kepribadian ekstrovert dan introvert dalam proses berpikir matematis dilihat dari tahapan indikator berpikir kritis dengan kepribadian yang dimiliki yang belum pernah diteliti oleh peneliti lain.

\section{Metode}

Penelitian ini merupakan penelitian kualitatif dengan menggunakan metode penelitian eksploratif yang bertujuan untuk mendeskripsikan data tentang bagaimana proses berpikir kritis siswa pada materi program linear berdasarkan tipe kepribadian ekstrovert dan introvert. 
Subjek penelitian merupakan siswa kelas XII TBB salah satu SMKN di Rajadesa melalui hasil penyebaran angket tipe kepribadian ekstrovert dan introvert. Berdasarkan hasil angket, siswa dibagi menjadi dua tipe kepribadian ekstrovert dan introvert. Dari setiap kelompok tipe kepribadian, secara bergiliran siswa melakukan tes kemampuan berpikir kritis sampai data yang diperoleh jenuh. Jumlah subjek yang diteliti adalah empat siswa, dimana dua siswa memiliki kepribadian ekstrovert dan dua siswa memilikii kepribadian introvert. Siswa yang telah dinilai kemampuan berpikir kritisnya yaitu presentase siswa tertinggi pada setiap kelompok tipe kepribadian.

Pengumpulan data dilakukan dengan menggunakan angket tipe kepribadian ekstrovert dan introvert, tes tertulis kemampuan berpikir kritis matematis dan wawancara. Angket tipe kepribadian ekstrovert dan introvert yang digunakan adalah angket yang diadopsi dari Eysenck Personality Inventory (EPI) (Eysenck, 2008: 55) yang merupakan alat baku untuk mengukur tipe kepribadian ekstrovert dan introvert.

Tes kemampuan berpikir kritis matematis siswa dilakukan setelah validator menyatakan validitas soalnya valid secara face validity dan content validity. Soal tes kemampuan berpikir kritis matematis berdasarkan indikator: merumuskan pokok-pokok permasalahan, merencanakan penyelesaian (memilih argumen yang logis), menganalisis informasi, melaksanakan rencana penyelesaian dan menarik kesimpulan. Metode pengumpulan data dalam penelitian ini menggunakan teknik Think Out Loud atau Think Aloud, yaitu metode penelitian dimana subjek mengungkapkan ide-idenya ketika menghadapi masalah, sehingga data yang dikumpulkan sangat langsung dan tidak ada penundaan, serta subjek tidak dapat memberikan interpretasi atas pemikirannya (Abadi, dkk., 2012:9).

Teknik analisis data dilakukan dengan langkah pengolahan data dan analisis data angket, menganalisis hasil tes berpikir kritis setiap subjek penelitian berdasarkan pengkodean, dan menggunakan model interaktif untuk hasil wawancara, yang unsur-unsurnya meliputi reduksi data (data reduction), penyajian data (data display), dan conclutions drowing/verifiying.

\section{Hasil dan Pembahasan}

Hasil tes tipe kepribadian ekstrovert dani introvert dapat dilihat dari gambar berikut:

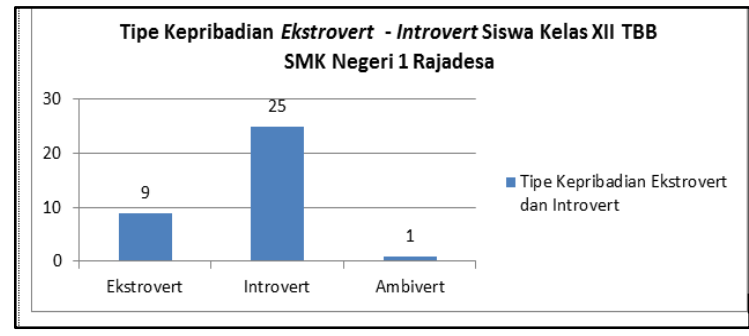

Gambar 1. Grafik Hasil Angket Ekstrovert-Introvert Siswa Kelas XII TBB SMKN 1 Rajadesa

Gambar 1 menunjukkan bahwa ditemukan sebanyak 25 siswa atau 71,43\% dari total keseluruhan 35 siswa 
menunujukkan bahwa siswa tersebut adalah introvert. Sedangkan siswa berkepribadian ekstrovert sebanyak 9 orang atau 25,71\%. Hal ini sesuai dengan hasil penelitian yang dilakukan oleh Arini, (2019: 130) bahwa angket tipe kepribadian yang digunakan dalam penelitiannya adalah EPI. Angket EPI diberikan kepada siswa kelas VIII-A SMP Negeri 3 Gresik, diperoleh 9 siswa berkepribadian ekstrovert dan 23 siswa berkepribadian introvert.

Berdasarkan hasil angket, sebanyak 4 siswa dijadikan subjek penelitian, yaitu S1 dan S3 dengan tipe kepribadian ekstrovert serta S2 dan S4 dengan tipe kepribadian introvert. Subjek diberi soal tes kemampuan berpikir kritis matematis dan wawancara satu per satu.

\section{A. S1 dan S3 (Siswa tipe kepribadian Ekstrovert)}

S1 pada lembar jawaban tidak menuliskan apa yang diketahui dan ditanyakan dari soal yang diberikan, tetapi berdasarkan hasil wawancara S1 mengetahui apa yang harus dicari dalam soal tersebut. Terlihat dari cara menjawab dan menuliskan jawabannya. S1 menulis jawaban dari data yang diketahui dan ditanyakan secara runtut dan terperinci.

S1 menjawab pertanyaan poin $1 b$ yang merupakan aspek menganalisis informasi dimana S1 dituntut untuk bisa menuliskan fakta dan pengetahuannya dan mempertimbangkan soal tersebut untuk mencari keuntungan. Hanya dalam mengambil kesimpulan S1 tidak menggunakan informasi ini untuk mencari keuntungan yang diperoleh sehingga jawaban yang diminta tidak terpenuhui. Hasil tersebut sesuai dengan hasil penelitian Fatmawati, dkk (2014: 916) bahwa salah satu faktor yang mempengaruhi proses berpikir kritis dalam menyelesaikan soal adalah rendahnya kemampuan siswa untuk mengubah soal cerita ke dalam model matematika, siswa cenderung menggunakan satu cara untuk menyelesaikan masalah tanpa memperhatikan cara lain. Oleh karena itu, siswa sering tidak mengecek hasil pekerjaannya kembali.

S1 selalu bertanya kepada peneliti setiap akan menuliskan jawabannya. S1 aktif bertanya ketika mengerjakan soal, untuk setiap langkahnya apa sudah benar atau belum. Pangestu dan Yunianta (2019: 224) memperkuat dengan hasil penelitiannya bahwa siswa berkepribadian ekstrovert mampu memahami maksud dari soal dengan membaca soal berulang-ulang dan cenderung memilih untuk bertanya kepada peneliti tentang hal-hal yang tidak dipahami. Dari soal terlihat bahwa setelah siswa menuliskan jawabannya dan mencari titik potong untuk grafik tersebut, siswa menyerah untuk melanjutkan penyelesaiannya. Dalam wawancara S1 mengatakan bahwa dia lupa langkah selanjutnya. Hasil penelitian Arini (2016: 130) menunjukkan bahwa siswa dengan berkepribadian ekstrovert dapat menemukan informasi dalam masalah tetapi tidak dapat menggunakan 
keterkaitan antar informasi-informasi tersebut.

S3 dalam lembar jawabannya menuliskan semua langkah dan aspek yang diukur dalam soal proses berpikir kritis yang diberikan secara lengkap dan tepat. Semua perhitungannya benar. Jawaban untuk pengambilan kesimpulan pun semuanya benar. S3 mampu mengerjakan soal dengan kriteria sulit dan berbeda dari soalsoal yang dicontohkan guru dengan sangat baik dan bisa dibilang dianggapnya mudah. Cara yang digunakan S3 dalam menentukan keuntungan maksimum yaitu dengan mencari terlebih dahulu nilai dari persentase keuntungan yaitu 40\% dan 20\% yang kemudian dikalikan dengan modal tiap tas yaitu 20.000 dan 30.000 dikalikan lagi dengan batas-batas setiap daerah himpunan penyelesaiannnya dan diperoleh nilai maksimumnya dengan tepat yaitu $\mathrm{Rp}$ 320.000 untuk penjualan tas pertama sebanyak 40 buah.

S3 tidak melakukan kesalahan sedikitpun ketika menyelesaikan soal. Dia merasa senang dan menunjukkan minat yang besar terhadap pelajaran matemtika. S3 termasuk kedalam kriteria siswa yang pintar dengan proses berpikir kritis matematis berkemampuan tinggi. Hal ini sesuai dengan penelitian yang dilakukan oleh Dominika dan Virlia (2018: 35) yang menunjukkan bahwa siswa ekstrovert lebih cenderung mengungkapkan setiap emosi yang mereka rasakan ketika menjalin komunikasi dengan orang-orang di sekitarnya. Siswa berkemampuan tinggi dapat menyelesaikan masalah dengan baik dan menyelesaikan semua tahapan proses berpikir kritis tanpa kesalahan.

\section{B. S2 dan S4 (Siswa tipe kepribadian Introvert)}

S2 tidak menuliskan data yang diketahui dan ditanyakan dengan benar dan jelas pada lembar jawaban. S2 tidak menuliskan model matematika secara lengkap dan tidak menuliskan nilai optimum yang diketahui. Tetapi S2 dapat menganalisis informasi yang diperoleh dari soal dengan benar. Pangestu dan Yunianta (2019: 224) memperkuat dengan hasil temuannya bahwa siswa introvert cenderung mengamati petunjuk dan informasi dengan cermat serta mengingat materi yang berkaitan dengan soal dan untuk hal yang belum dipahami subjek introvert cenderung bertanya kepada temantemannya.

S2 menggunakan pengetahuannya untuk menggali informasi ini dan membuat kesimpulan yang logis dari hasil analisisnya. Meskipun perhitungannya tidak tepat tetapi jawabannya masuk akal dan bisa diterima meskipun cara yang digunakan berbeda dengan apa yang diajarkan guru. Arini (2016: 134) memperkuat dengan hasil penelitiannya bahwa siswa berkepribadian introvert dapat menemukan dan menggunakan keterkaitan antara informasi yang ada dalam pertanyaan yang diberikan. Subjek introvert tenang dan berpikir sebelum membuat sebuah kesimpulan. S2 tidak menggambar grafik untuk menentukan daerah himpunan 
penyelesaian. S2 hanya mencari titik potong yang seharusnya digunakan untuk menentukan perpotongan 2 garis dalam grafik. Hal ini berakibat pada langkah menggunakan uji titik pojok untuk mencari keuntungan maksimum, S2 tidak menyelesaikannya. S2 memiliki ide untuk mencari nilai maksimum sendiri dengan mensubstitusi nilai dari variabel $x$ dan variabel $y$ yang dicari dari mencari titik potong ke persentase yang diketahui dari soal. Walaupun cara menentukan keuntungan maksimum berbeda dengan yang dicontohkan guru tapi idenya sudah tepat.

Dalam mengerjakan soal tes berpikir kritis yang diberikan, S4 mampu menyelesaikannya dengan rinci. Tetapi S4 tidak menuliskan nilai optimum yang diketahui dan tidak menggunakannya ketika menggunakan uji titik pojok untuk mencari keuntungan maksimum. Hal ini berdampak pada pengambilan kesimpulan yang menjadikan jawaban S4 dalam menyelesaikan masalahnya tidak tepat. Tahap akhir dalam mengambil kesimpulan S4 tidak menghitung semua batas-batas dari daerah himpunan penyelesain, walaupun dalam uji titik pojok perhitungannya tepat, meskipun S4 tidak

munuliskan nilai $z$ nya dalam mencari keuntungan tetapi peneliti menyimpulkan bahwa S4 ini memahami apa yang harus dicari dan ditanyakan dari soal ini. Kesalahan yang dilakukan S4 adalah tidak mencari semua keuntungan untuk setiap titik dari batas yang sudah ditentukan. S4 menyimpulkan bahwa jika modal yang dikeluarkan makin tinggi maka keuntungan pun akan makin besar. Terlihat dari kesimpulan dengan mengambil angka 1.000.000 sebagai keuntungan terbesar.

S4 hanya menghitung jika memproduksi tas jenis I sebanyak 20 buah dan tas jenis II 20 buah juga harus mengeluarkan modal sebanyak 1.000.000 dengan keuntungan Rp280.000. Tetapi jika dihitung untuk memproduksi tas model I saja sebanyak 40 buah modal yang diperlukan sebanyak 800.000, dengan keuntungan lebih besar yaitu 40\% dikali 800.000 dikali 40 menjadi Rp320.000, maka keuntungan yang didapat melebihi yang menggunakan modal 1.000.000 dikarenakan persentase keuntungan tiap jenis tas berbeda. Berdasarkan deskripsi proses berpikir kritis matematis subjek penelitian sebanyak empat orang di atas, berikut analisis perbedaan proses berpikir kritis siswa berdasarkan tipe kepribadiannya.

Tabel 1.

Perbedaan Proses Berpikir Kritis Siswa Tipe Kepribadian Ekstrovert dan Introvert

\begin{tabular}{lll}
\hline $\begin{array}{c}\text { Proses } \\
\text { Berpikir } \\
\text { Kritis }\end{array}$ & \multicolumn{1}{c}{ Ekstrovert } & \multicolumn{1}{c}{ Introvert } \\
\hline Merum & Secara umum subjek ekstrovert tidak & Secara keseluruhan subjek introvert \\
uskan & menuliskan apa yang diketahui dan & sebenarnya memahami langkah apa yang \\
pokok- & ditanyakan pada permasalahan, subjek & harus diambil dan bagaimana \\
pokok & ekstrovert masih belum mengerti bagaimana & mengerjakannya, hal ini ditunjukkan pada saat
\end{tabular}




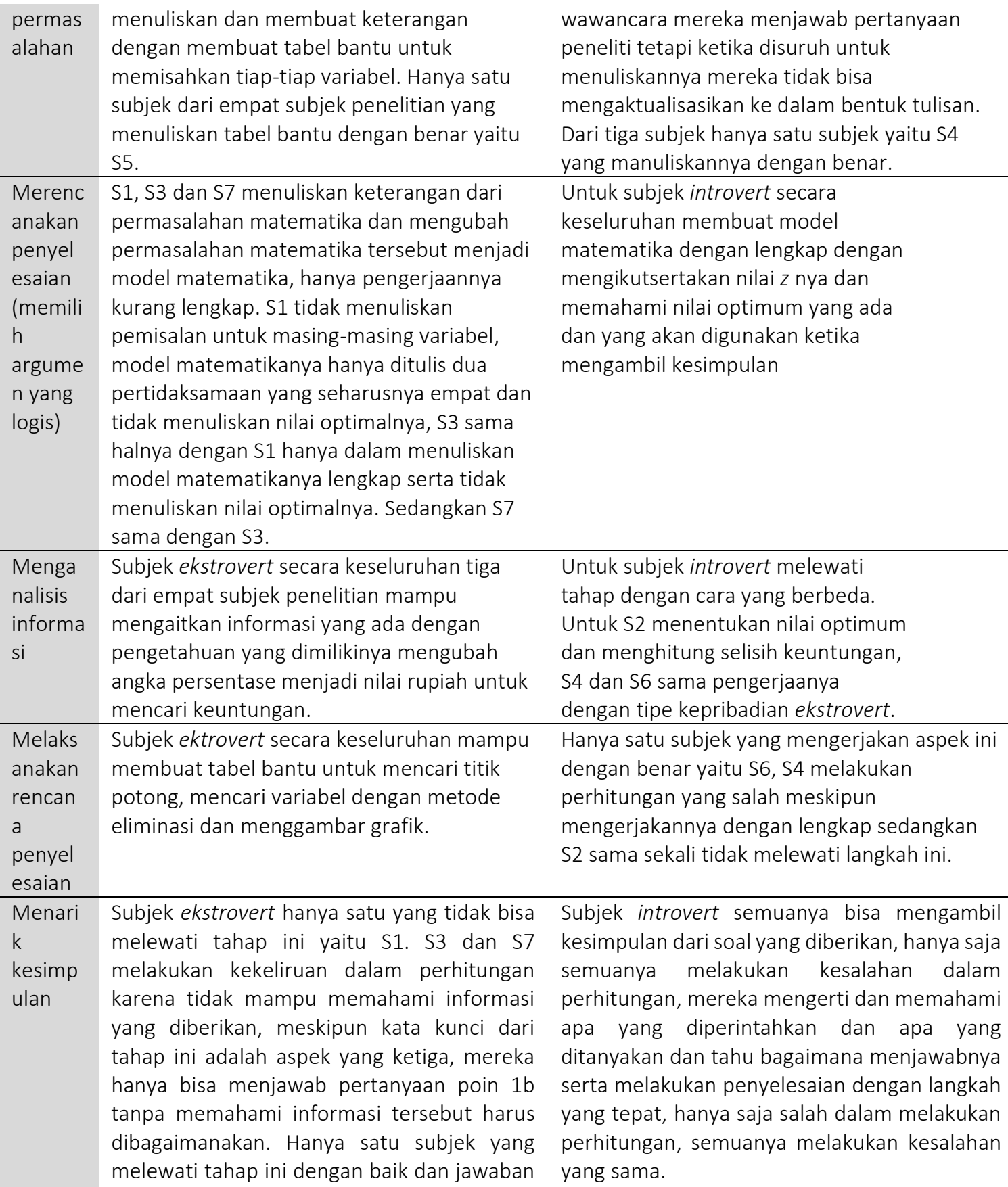

wawancara mereka menjawab pertanyaan peneliti tetapi ketika disuruh untuk menuliskannya mereka tidak bisa mengaktualisasikan ke dalam bentuk tulisan. Dari tiga subjek hanya satu subjek yaitu S4 yang manuliskannya dengan benar. Untuk subjek introvert secara keseluruhan membuat model matematika dengan lengkap dengan mengikutsertakan nilai $z$ nya dan memahami nilai optimum yang ada dan yang akan digunakan ketika mengambil kesimpulan

Untuk subjek introvert melewati tahap dengan cara yang berbeda. Untuk S2 menentukan nilai optimum dan menghitung selisih keuntungan, S4 dan S6 sama pengerjaanya dengan tipe kepribadian ekstrovert.

Hanya satu subjek yang mengerjakan aspek ini dengan benar yaitu S6, S4 melakukan perhitungan yang salah meskipun mengerjakannya dengan lengkap sedangkan S2 sama sekali tidak melewati langkah ini.

Subjek introvert semuanya bisa mengambil kesimpulan dari soal yang diberikan, hanya saja semuanya melakukan kesalahan dalam perhitungan, mereka mengerti dan memahami apa yang diperintahkan dan apa yang ditanyakan dan tahu bagaimana menjawabnya serta melakukan penyelesaian dengan langkah yang tepat, hanya saja salah dalam melakukan perhitungan, semuanya melakukan kesalahan yang sama.

Analisis proses berpikir kritis matematis siswa dengan tipe kepribadian ekstrovert dan introvert ditunjukkan pada tabel berikut: 
Tabel 2.

Aspek Proses Berpikir Kritis Siswa Ditinjau Dari Tipe Kepribadian Ekstrovert-Introvert

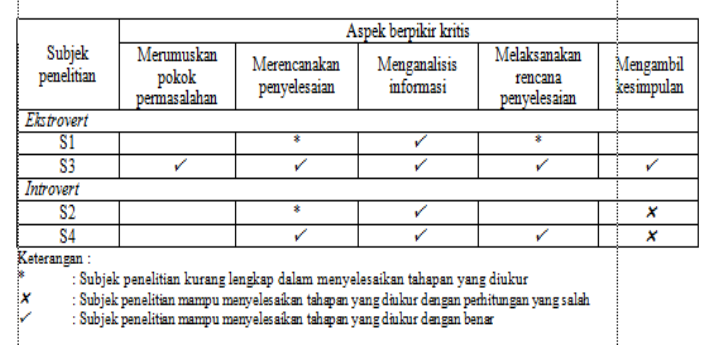

Dari analisis data, peneliti dapat mendeskripsikan proses berpikir kritis matematis siswa ditinjau dari tipe kepribadian ekstrovert dan introvert pada materi program linear. Sejalan dengan penelitian Pangestu dan Yunianta (2019), siswa dengan tipe kepribadian introvert cenderung dapat menyelesaikan soal dengan melalui tahap proses berpikir kritis, yaitu menganalisis informasi, merencanakan penyelesaian dan mengambil kesimpulan. Artinya pemahaman soal, konsep, penyelesaian soal serta mengungkapkan ide untuk penyelesaian soal yang berbeda dapat ditempuh meskipun dari kedua subjek penelitian tidak menyelesaikan semua tahap proses berpikir kritis. Baik dalam menyelesaikan permasalahan yang diberikan maupun menjawab pertanyaan penelitian, subjek introvert kurang cepat dibandingkan dengan subjek ekstrovert.

\section{Penutup}

Subjek ekstrovert lebih cepat dibandingkan dengan subjek introvert dalam menyelesaikan masalah. Secara umum kesalahan yang dilakukan oleh subjek ekstrovert adalah mengabaikan informasi dari soal. Siswa introvert dapat menemukan dan menggunakan keterkaitan antara informasi dalam permasalahan. Selain itu, subjek introvert juga dapat menulis deskripsi masalah matematika dengan mengubah masalah yang diketahui menjadi model matematika untuk merencanakan solusi atau memilih argumen yang logis. Dalam hal memecahkan pertanyaan yang diberikan dan menjawab pertanyaan peneliti, subjek introvert tidak secepat subjek ekstrovert, intovert lebih tenang, teliti, dan berhatihati saat menarik kesimpulan.

\section{Daftar Pustaka}

Afriansyah, E. A., Herman, T., Turmudi, \& Dahlan, J. A. (2021, February). Critical thinking skills in mathematics. In Journal of Physics: Conference Series (Vol. 1778, No. 1, p. 012013). IOP Publishing.

Abadi, R. M. D., Jahandar S., Khodabandehlu M., \& Seyedi G. (2012). The Think-aloud Method in EFL Reading Comprehension International. Journal of Scientific \& Engineering Research, 7(1) 103-112.

Alexandra, G., \& Ratu, N. (2018). Profil Kemampuan Berpikir Kritis Matematis Siswa SMP Dengan Graded Response Models. Mosharafa: Jurnal Pendidikan Matematika, 8(2).

Apiati, V., \& Hermanto, R. (2020). Kemampuan Berpikir Kritis Peserta 
Didik dalam Memecahkan Masalah Matematik Berdasarkan Gaya Belajar. Mosharafa: Jurnal Pendidikan Matematika, 9(1), 167-178.

Arini, Z., \& A. H. R. (2016). Profil Kemampuan Penalaran Siswa SMP dalam Menyelesaikan Masalah Matematika Ditinjau dari Tipe Kepribadian Extrovert dan Introvert. MATHE Dunesa, 2(5), 127-136.

De raad, B., \& Schouwenburg H. C. (1996). Personality In Learning and Education: A Riview. European journal of personality: Scientific Research. 10, 303-336.

Dominika, \& Virlia, S. (2018). Hubungan Tipe Kepribadian Ekstrovert-Introvert dengan Penerimaan Sosial Pada Siswa. KONSELOR, 7(1), 31-39.

Donnellan, M. B., \& Robins R. W. (2010). Resilient, Overcontrolled and Undercontrolled Personality Types: Issues and controversies. Social and Personality Psychology Compass, 4, 1070-1083.

Ennis, R. H. (1989). Critical thinking and subject specificity: Calrification and neededresearc. Educational Researcher, 18(3), 4-10.

Eysenck, H. J. \& Wilson, G. D. (2008). Know Your Own Personality. Anglesburg: Pelican.

Facione, P. A. (1994). Holistic Critical Thinking Scoring Rubric. California: California Academic Press.

Fatmawati, H., Mardiyana, \& Triyanto. (2014). Analisis Berpikir Kritis Siswa
Dalam Pemecahan Masalah Matematika Berdasarkan Polya Pada Pokok Bahasan Persamaan Kuadrat (Penelitian pada Siswa Kelas X SMK Muhammadiyah 1 Sragen Tahun Pelajaran 2013/2014). Jurnal Elektronik Pembelajaran Matematika, 2(9), 899-910.

Friedman, H. S., \& Schustack, M. W. (2008). Kepribadian teori klasik dan riset modern. Jakarta: Erlangga.

Halpern D. (2003). Thought \& Knowledge: An Introduction to Critical Thinking. Lawrence Erlbaum Associates. London: Mahwah, New Jersey.

Janssen, E., Wietse M., Tim, M., Peter P. J. L. V., Anita H., Lara M. V. P. \& Tamara V. G. (2019). Identifying Characteristics Associated With Higher Education Teachers' Cognitive Reflection Test Performance and Their Attitudes Towards Teaching Critical Thinking. Teaching and Teacher Education Journal, 84, 139-149.

Jesse, S. A., Paula N. O., \& Robert O. D. (2006). Matching Strudent Personality Types and Learning Preferences to Teashing Methodogies. Journal of Dental Education, 70(6), 644-651.

Kesumawati, N. (2012). Disposisi Matematis. http://staff.uny.ac.id.

Kusmanto, Hadi. (2014). Pengaruh Berpikir Kristis Terhadap Kemampuan Siswa Dalam Memecahkan Masalah Matematika (Studi Kasus Di Kelas VII SMP Wahid Hasyim Moga). EduMa, 3(1). 
Luritawaty, I. P., \& Prabawanto, S. (2021). Pre-Service Teacher's Difficulty Employing Critical Thinking To Solve Mathematical Problem. Bordeless Education in a Challenge in the 5.0 Society, London: Taylor \& Francis Group.

Masfufah, R., \& Afriansyah, E. A. (2021). Analisis Kemampuan Literasi Matematis Siswa melalui Soal PISA. Mosharafa: Jurnal Pendidikan Matematika, 10(2), 291-300.

Muhtadi, D., Supratman and Hermanto, R. (2019). The students' mathematical critical thinking process reviewed from the cognitive style. Journal Physics: Conference Series.

Pangestu, N. S. \& Yunianta, T. N. H. (2019).

Proses Berpikir Kreatif Matematis Siswa Esktrovert dan Introvert SMP Kelas VIII Berdasarkan Tahapan Wallas. Mosharafa: Jurnal Pendidikan Matematika, 8(2).

Pervin, L. A. (1996). Personality: A view of the future based on a look at the past. Journal of Research in Personality, 30(3), 309-318.

Rezaei, S., Ali D., \& Marzieh B. (2011). Critical Thinking in Language Education. Journal of Language Teaching and Research, 2(4), 769-777.

Sri, K. W., \& Yohanes, K. H. (2013). Perbedaan Intensitas Komunikasi Melalui Jejaring Sosial antara Tipe Kepribadian Ekstrovert dan Introvert pada Remaja. Jurnal Psikologi Udayana, 1(1), 106-115.
Suryabrata, S. (2010). Psikologi kepribadian. Jakarta: PT Rajawali Pers. Weller B. F. (2005). Kamus Saku Perawat. Edisi 22. Jakarta: EGC.

Yeh, Mei-Ling., \& Hsing-hsia Chen. (2003). Effects of An Educational Program With Interactive Videodisc Systems In Improving Critical Thinking Dispositions For RN-BSN Students In Taiwan. International Journal of Nursing Studies.

\section{Riwayat HidUP PENULIS}

\section{Rindu Rudianti, M.Pd.}

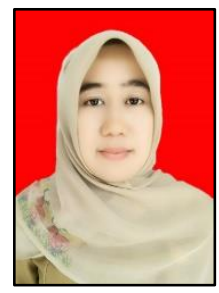

Lahir di Ciamis, (8 September 1990). Staf pengajar di SMKN 1 Rajadesa. Studi S1 di Fakultas Keguruan dan Ilmu Pendidikan, bidang Studi Pendidikan Matematika Universitas Siliwangi, Tasikmalaya, lulus tahun (2012); dan S2 Pascasarjana Pendidikan Matematika Universitas Siliwangi, Tasikmalaya, lulus tahun (2021).

Prof. H. Aripin, Ph.D.

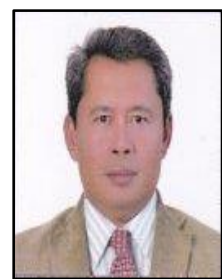

Dosen di Universitas Siliwangi.

\section{Dedi Muhtadi, M.Pd.}

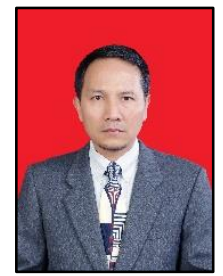

Dosen di Universitas Siliwangi, Tasikmalaya. Studi S3 Pendidikan Matematika Universitas Negeri Semarang sampai dengan sekarang. 